\title{
Organizational Justice and Workplace Bullying: Lessons Learned from Externally Referred Complaints and Investigations
}

\author{
Annabelle M. Neall ${ }^{1, * \mathbb{C}}$, Yiqiong $\mathrm{Li}^{2}$ and Michelle R. Tuckey ${ }^{3}$ \\ 1 School of Psychology, University of Queensland, Brisbane 4072, Australia \\ 2 UQ Business School, University of Queensland, Brisbane 4072, Australia; yiqiong.li@business.uq.edu.au \\ 3 UniSA Justice \& Society, University of South Australia, Adelaide 5001, Australia; \\ michelle.tuckey@unisa.edu.au \\ * Correspondence: a.neall@uq.edu.au
}

\section{check for} updates

Citation: Neall, A.M.; Li, Y.; Tuckey, M.R. Organizational Justice and Workplace Bullying: Lessons Learned from Externally Referred Complaints and Investigations. Societies 2021, 11, 143. https://doi.org/10.3390/ soc 11040143

Academic Editors: Margaret Hodgins, Patricia Mannix McNamara,

Loredana Ivan, George Jennings and Gregor Wolbring

Received: 30 April 2021

Accepted: 30 November 2021

Published: 3 December 2021

Publisher's Note: MDPI stays neutral with regard to jurisdictional claims in published maps and institutional affiliations.

Copyright: (c) 2021 by the authors. Licensee MDPI, Basel, Switzerland This article is an open access article distributed under the terms and conditions of the Creative Commons Attribution (CC BY) license (https:// creativecommons.org/licenses/by/ $4.0 /)$.

\begin{abstract}
Workplace bullying is a serious psychosocial risk which, when poorly managed, results in detrimental outcomes for individuals, organizations, and society. Some of the most common strategies for addressing bullying within the workplace centre on attempts to document and contextualise the bullying situation-that is, the internal complaint and investigation process. Scholarly inquiries of these investigative mechanisms, however, are limited, and most have neglected the influence of organisational justice as an underpinning mechanism in explaining complainant dissatisfaction. Using evidence from 280 real-life cases of workplace bullying lodged with a peak work, health, and safety agency, we identify how organizational justice manifests in externally referred cases of workplace bullying. Specifically, we match complainant evaluations of the internal complaint and investigation handling process to domains of organisational justice, thereby ascertaining potential threats to efforts to effectively manage and prevent bullying in the workplace. Four types of justice-distributive, procedural, interpersonal, and informational-were identified within the cases. Specifically, in cases of workplace bullying where distributive justice is not upheld (usually by virtue of unsubstantiated claims), the way in which information is gathered and decisions are made (procedural), the way in which the parties are treated (interpersonal), and the timeliness and validity of explanations provided (informational) are all cited by complainants as key factors in their decision to escalate the complaint to an external investigative body. These results signal the need for timely, clear, and compassionate investigative processes that validate complainants' experiences and serve as a tool for rebuilding trust and repairing damaged relationships in the workplace.
\end{abstract}

Keywords: workplace bullying; organisational justice; investigations; complaints

\section{Introduction}

Workplace bullying is a challenging occupational hazard that negatively impacts the health and wellbeing of individuals, teams, and organizations [1]. While there is no universally agreed upon definition for workplace bullying, it is commonly regarded as harassing, offending, or socially excluding actions, repeated regularly over a period of time (usually six months), between two or more parties who hold different levels of power. Data from Nielsen et al.'s [2] meta-analysis indicated that approximately $15 \%$ of employees are exposed to some level of workplace bullying globally.

The harmful and detrimental effects of workplace bullying are widely documented in the academic literature. For individuals, exposure to workplace bullying can trigger mental and physical health problems, burnout, strain, decreased job satisfaction, and diminished organizational commitment [3]. The effects of bullying are not just limited to targetswitnesses of workplace bullying are more likely to report decreased self-esteem and lessened job, co-worker, supervisor, and health satisfaction as compared to employees who 
do not witness bullying [4,5]. Organizational functioning is also impaired by workplace bullying, with several studies demonstrating a significant correlation between workplace bullying and increased absenteeism and turnover, and decreased productivity [6-8].

As the detrimental effects of workplace bullying become more evident, scholarly investigation has turned to how best to manage and prevent bullying and its negative effects. A key strategy in addressing workplace bullying is encouraging victims and other affected parities (e.g., bystanders and health and safety representatives) to report bullying behaviour when it occurs via internal reporting mechanisms (e.g., lodging a complaint) $[9,10]$. Following a complaint, an internal investigation may be launched to establish facts about the circumstances leading to the bullying event(s), to provide an opportunity for all parties to put the events in context, and to determine a response to the matter that may or may not lead to disciplinary action, in line with the organization's behavioural or code of conduct policy [11].

The efficacy of the internal complaint and investigation process remains dubious [9], with little scholarly study of the extent to which internal workplace bullying complaints are successful and the factors that allow these internal complaints to be resolved successfully. For those victims whose cases are not handled or poorly handled, they may resort to external government authorities for investigation and intervention. In these externally referred cases, issues concerning organizational justice are highly relevant, because it is likely for these victims to feel unfairness and frustration about how their cases are dealt by the internal complaint and investigation process.

Organizational justice is concerned with fairness and consideration in the workplace [12] and can be defined as "the extent to which employees are treated with justice at their workplace" [13]. Put simply, "people expect to be treated fairly, and they experience a shock to their systems when they believe this has not occurred" [14]. In applying the organizational justice lens to understand workplace bullying, the 'shock to the system' might come from exposure to the behaviour itself and, separately, from how the organization fails to handle the bullying complaint. In workplace bullying literature, organizational justice has typically been explored as either an antecedent of perceptions of bullying [15-17], or as a moderator of the effects of bullying [18]. In contrast, little is known about how justice reactions or perceptions of injustice are triggered within the bullying complaints and investigation process. This issue is especially important in the cases for which the internal investigation process failed to result in a satisfactory solution. Addressing this gap in knowledge is vital for informing intelligence-led responses to bullying that does occur within organizations.

Accordingly, in the present research, we analyse a sample of workplace bullying complaints that were escalated from internal complaints to an external investigation with the local work health and safety agency. Our research question is: How do issues of organizational justice manifest among the externally refereed workplace bullying cases in relation to the internal workplace bullying complaint and investigation process? In answering this question, the contributions of this study are two-fold. First, we generate new knowledge on the internal workplace bullying complaints and investigation process in a way that has meaning at the level of individual experiences of the complainants, while also grounding the findings in key principles of organizational justice to identify transferable insights. Second, investigating how justice manifests within the investigation and complaints processes for the externally refereed workplace bullying cases provides clear intervention points for optimising the way organizations handle workplace bullying complaints. This has many flow-on effects, including (a) curbing interpersonal conflict in its early stages (thus preventing the need for escalation to criminal prosecution), (b) correcting the culture and norms around what is considered acceptable workplace behaviour between colleagues (thereby reducing likelihood of bullying in the future), and (c) restoring employee justice perceptions (which have been shown to have impact on employee performance, wellbeing, and interpersonal relationships) $[19,20]$. 


\subsection{Workplace Bullying Complaint and Investigation Process}

A cornerstone strategy for managing workplace bullying often occurs after the bullying has taken place, via a form of complaint or reporting instrument-that is, "when an individual employee notifies the organization that there is a specific bullying incident with the expectation of a response to address their situation" [9]. Typically lodged by the target of the bullying behaviour, complaints can take the form of an informal conversation with, or email to, management, through to official requests for investigation lodged with a human resources representative, or even application to Stop Bullying through an employment tribunal $[9,21]$. Complaints are often regarded as a means to seek redress from an ordeal, where actions are implemented following rounds of inquiry. However, research has noted significant variation in the rate of registered incidents of bullying within organisations comparative to self-labelled prevalence rates, suggesting several barriers to the reporting of bullying [22].

While lodging a complaint can itself be a lengthy and nonlinear process, complaints often trigger a thorough analysis of the offending events. Specifically, a workplace bullying investigation may be regarded as "a process to determine the facts prior to decision making by the employer" [23]. Similar to bullying complaints, there have been few academic studies of the purpose, process, and practice of workplace bullying investigations, despite a clear, repeated mandate from health and safety bodies to implement fair, objective, and thorough investigative processes [24]. Potential outcomes of the investigation processes are varied, from informal attempts to restore the working relationship, through to an official hearing within the organization, or legal action driven by outside council to apply punitive consequences to the individuals or organization responsible for the bullying behaviour $[9,25]$. However, there is a growing consensus that investigations primarily serve to demonstrate organisational compliance with policy, legislation, and regulations, rather than to establish factors and reprimand perpetrators or modify the contributing individual/system factors that underpin bullying behaviour [23].

When implemented effectively, the process of handling complaints and undertaking investigations has the potential to re-establish fairness and provides an opportunity to signal that bullying behaviour is taken seriously in the organization and will not be tolerated [26]. If the complaints are not handled or handled poorly by the internal investigation process, this will have significant impact on employee perceptions of organizational justice, not only in relation to the outcome of their bullying complaints but also how the complains is dealt and how they are treated. In other words, organizational justice is a key factor in the resolution of bullying situations, yet few studies have explored the role of organizational theory as an explanatory mechanism.

\subsection{Organizational Justice and Workplace Bullying}

According to fairness heuristic theory, employees rely on justice-relevant information to understand, evaluate, and react to what is happening in their organization [27-29] especially when faced with uncertainty [30]. In relation to workplace bullying, employees who have been exposed to bullying may be unsure if and how such issues can be addressed, if they can trust their organization in managing the risk and mitigating the negative impact of bullying, and if lodgement of a bullying complaint will bring negative ramifications upon their career, personal life, and health.

The justice literature primarily centres on experienced justice, manifested in four dimensions, namely distributive, procedural, interpersonal, and informational justice [31]. In relation to our study with a focus on internal investigations of workplace bullying for externally referred workplace bullying complaints, experienced justice describes employees' perceptions of the treatment they have received from their organizations and the significant parties in their organizations after lodging a formal bullying complaint internally and prior to their decision to resort externally. In other words, experienced justice, in our research context, captures to what extent complainants perceive the investigation procedure itself 
(including the outcome), personal treatment received during the investigation process, and accounts and explanations offered about the investigation process as fair.

We expect that all four dimensions of justice [31] could manifest in employees' experience of the internal investigations of workplace bullying. Procedural justice, referring to the extent to which decision-making procedures and processes are perceived to be consistent, bias-free, accurate, correctable, ethical, and representative [32], manifests in how a bullying complaint is made and is investigated and the way in which an outcome is determined. for example, the transparency of the process through which decisions are made and the opportunity for all parties to have meaningful input [33]. Distributive justice, defined as the perceived fairness of the decision outcomes or the distribution of outcomes judged in principles of equity, equality, and need [34], is concerned with the consequences of, or specific decisions made arising from, the investigation. Interpersonal justice relates to whether individuals are treated in a polite, dignified, and respectful way [19] by authorities or third parties involved in implementing procedures or determining outcomes. In relation to our study, interpersonal justice reflects how a complainant is treated with interpersonal sensitivity throughout the complaint and investigation process. Informational justice perceptions emerge upon justifications and explanations provided by organizational authorities [19], with individuals assessing to what extent such justifications and explanations are accurate, sufficiently justified, and delivered in a timely manner by means of honest communication. In relation to internal investigation, informational justice perceptions focus on the accounts and explanation offered to complainant about reasons as to how certain investigation procedures were chosen and implemented and how certain investigation outcomes were finalized.

Although the four dimensions of experienced justice perceptions are worthy of study in their own right, and each has contributed substantially to employee attitudinal and behavioural outcomes, it does not necessarily mean all four types of justice must be in place simultaneously to result in justice perceptions. For example, employees are more willing to accept an unwanted or undesirable outcome if they believe that the decision-making process used to arrive at such decision was conducted in accordance with the six procedural justice rules [32], termed the "fair-process" effect [35-38]. When employees perceive interpersonal and informational justice, employees typically view decisions as fairer, even if they are unfavourable/undesirable [37]. This suggests that a favourable distributive outcome is not the only way to make victims feel fair in relation to internal investigation.

These four dimensions of experienced justice perceptions begin to develop after victims lodge a bullying complaint and are largely influenced by perceptions of predicted or anticipatory justice, defined as expectations of justice in future events [39,40]. For example, employees will try to predict whether investigation procedures will be fair (procedural), if investigation outcome will be fair and impartial (distributive), if they will be treated respectfully (interpersonal), and if they will be offered with justified explanation (informational) when they lodge a complaint. A handful of empirical studies show that anticipatory justice impacts how employees react to organizational changes [30]. If employees question an organizations' capacity in handling internal investigation in a fair way and anticipate the absence of any or all of the four dimensions of justice, this may prevent them from filing a formal complaint. Rudman, Borgida, and Robertson [41] found that women are more reluctant to report sexual harassment when they suspect that the investigation process will not be organized in a fair manner. Victims also have less confidence in an organizations' ability to deal effectively with workplace bullying incidents, particularly when perpetrators are their supervisors [42]. In contrast, when employees have high perceptions of foreseen organizational justice, they are more likely to pursue a lawsuit in response to sexual harassment in workplace [43].

\subsection{Evaluating Bullying Investigations through a Justice Lens}

The bullying complaint process has been investigated through various lenses to date, including disciplinary matters, health and safety, and whistleblowing [9], but scarcely 
through the justice context. Only a handful of studies have explored the notion that victims of workplace bullying evaluate their experience of the complaint/investigation/outcome process through a justice lens $[16,42,44]$ and even fewer have connected the complaint/ investigation process to organisational justice-that is, when targets of workplace bullying make a complaint and do not achieve justice restoration, they feel dissatisfied $[45,46]$. For example, Jenkins and colleagues' [33] study of Australian bullying complainants suggests that participants who submitted a workers' compensation claim perceived less organisational justice in the way their complaint of bullying was managed internally than those participants who did not submit a claim. However, it is not yet known what forms of justice are violated through the workplace bullying complaint and investigation process. It is evident from previous studies of organisational justice that complainants who do not experience the outcome they want or expect experience a violation of distributive justice, and that this may apply to cases of workplace bullying. Similarly, when complainants perceive the investigation process to be biased or dissatisfactory, they may seek recourse to restore procedural justice. It is possible, however, that there may be multiple violations within a single case (i.e., possible joint effects)_for example, a complainant who feels their grievance has not been taken seriously (i.e., poor procedural justice) may seek further intervention if they believe the organization did not take appropriate action (i.e., a form of distributive justice) and that their complaint was not conducted in line with how other complaints had been handled (i.e., informational justice). Similarly, complainants whose claims are not substantiated (i.e., a lack of distributive justice) may feel scared and unsupported during the investigation process (i.e., interpersonal justice) and find it difficult to raise a complaint within the organisation (i.e., procedure justice).

The focus of this study was thus to understand how the externally referred workplace bullying complaints have been handled and subsequently investigated within organizations through an organizational justice lens. The data represent a rich and contextually detailed source on how externally referred workplace bullying complainants evaluate the internal complaint and investigation process, in terms of the restoration of organizational justice. Specifically, the data were sourced from case files where Australian employees felt they had been exposed to workplace bullying and who sought further intervention from the state work health and safety regulator (i.e., SafeWork SA) following an unsuccessful internal investigation process. These participants filed a request for investigation into alleged workplace bullying, and the documentation from subsequent investigations was transcribed and analysed. Examining the data in this way provides insights in optimising the process for addressing workplace bullying by capturing the key forms of organisational justice that foster resolution and constructive outcomes.

\section{Method}

\subsection{Data Collection}

Data for this study were sourced from the peak health and safety body of one Australian state-SafeWork South Australia (SA). SafeWork SA provides advice and education on work health and safety, enforces legislation pertaining to health safety and workplace relations, and instigates workplace incidents or suspected violations of the health and safety act, including a failure to maintain a psychologically healthy workplace. Between January 2006 and March 2013, over 1200 requests for investigation into alleged workplace bullying were opened with SafeWork SA. Upon examination of the quality of the case file materials, it was decided to utilise files from 2010 onwards (totalling 540 cases). Of these, 55 files were still under investigation with SafeWork SA at the time of data collection, and the outcome of the investigation was not confirmed. A further 140 files were not available for transcription, as the hard copy files could not be located. Twenty-nine cases contained insufficient information about the case and were therefore deemed unsuitable for examination. An additional 27 cases were related to non-bullying matters, such as non-psychosocial occupational health and safety breaches, fraud, WorkCover claims, and common assault. In these cases, investigators from SafeWork SA assisted the complainant 
with finding the correct government department to deal with their issue. These cases were subsequently removed from the analysis. Thus, a total of 289 files were available, which were transcribed and analysed in the current study.

The cases contained a variety of information related to the case-we captured evidence provided by the complainant, email communications, and records and results of the investigation process from the SafeWork SA investigator. Some cases had more than 480 pages of information; others contained as few as 10 pages. The selected cases were electronically transcribed onsite by an independent agency and then imported into NVivo V10 for analysis.

\subsection{Data Analysis}

Data were thematically analysed [47] according to employee perceptions of bullying complaint and investigation processes and outcomes. Specifically, data were initially coded to determine the characteristics of the complaint/investigation (i.e., perpetrator role, reporting personnel, method of complaint submission) and the core aspects of the complaint/investigation process (i.e., the outcome of internal investigation and the reason for escalation to SafeWork SA). A subsequent round of coding identified different evaluations of the internal complaint and investigation process (e.g., complaint was not taken seriously, or investigation was biased towards perpetrator), which were dually coded by the lead author and research assistant. In the final stage, evaluations were paired to corresponding domains of organisational justice, with any discrepancies in matching resolved through discussion with all authors. All data were coded exhaustively (i.e., all forms of justice, methods of complaint submission, reporting persons, and perpetrators were recorded).

\section{Results}

\subsection{Complaint Characteristics}

Data were analysed to determine the gender of the complainant(s) and alleged perpetrator(s), along with the industry of work where the complaint occurred (see Table 1). This analysis revealed that women were more likely to be targets of workplace bullying ( $n=166$, males $=117)$ but less likely to perpetrate bullying behaviour $(n=118$, males $=161)$. Additionally, the most prevalent industries to raise a complaint with SafeWork SA were health and community services $(n=43)$; accommodation, cafes, and restaurants $(n=23)$; and education $(n=21)$.

Table 1. Gender of Complainant, Alleged Perpetrator in Relation to the Complaint and Industry that Complaint Occurred.

\begin{tabular}{|c|c|c|c|c|c|}
\hline \multirow{2}{*}{$\begin{array}{c}\text { Complainant Gender } \\
\text { Female }\end{array}$} & \multirow{2}{*}{$\begin{array}{c}n \\
166\end{array}$} & \multicolumn{4}{|c|}{ Complainant Industry $n$} \\
\hline & & $\begin{array}{l}\text { Accommodation, cafes, } \\
\text { and restaurants }\end{array}$ & 23 & $\begin{array}{c}\text { Health and } \\
\text { community services }\end{array}$ & 43 \\
\hline Female and Male & 1 & $\begin{array}{l}\text { Agriculture, forestry, } \\
\text { and fishing }\end{array}$ & 3 & Manufacturing & 12 \\
\hline Male & 117 & Communications services & 1 & Mining & 1 \\
\hline Not disclosed & 5 & Construction & 10 & Personal and other services & 6 \\
\hline Perpetrator Gender & $n$ & $\begin{array}{l}\text { Cultural and } \\
\text { recreational services }\end{array}$ & 7 & $\begin{array}{c}\text { Property and } \\
\text { business services }\end{array}$ & 5 \\
\hline Female & 118 & Education & 21 & Retail trade & 20 \\
\hline Male & 161 & $\begin{array}{l}\text { Electricity, gas, and } \\
\text { water supply }\end{array}$ & 1 & Transport and storage & 12 \\
\hline $\begin{array}{l}\text { Multiple persons (Gender } \\
\text { not specified) }\end{array}$ & $8^{*}$ & Finance and insurance & 7 & Wholesale trade & 2 \\
\hline Not disclosed & 37 & $\begin{array}{c}\text { Government } \\
\text { administration/defence }\end{array}$ & 10 & Not disclosed & 105 \\
\hline
\end{tabular}

NOTE: In 68 cases, there was no evidence of an internal complaint being submitted. In 43 cases, the outcome of the complaint was not disclosed (in case files). In 15 cases, no complaint was not lodged (confirmed) (no reason given). ${ }^{*}$ Refers to number of cases, not individuals. 
The working relationship between the complainant and the alleged perpetrator was also coded. In 54 cases, the relationship between the complainant and alleged perpetrator could not be ascertained due to incomplete information; thus, 235 cases were included in this analysis. In over two-thirds of the cases, a direct supervisory figure was the alleged perpetrator of the bullying. Managers were the most reported direct supervisory figure, along with supervisors and team leaders. In one-sixth of cases, the perpetrator was reported to be a higher-level manager-that is, the alleged perpetrator held some form of power over the victim but did not necessarily oversee their work on a day-to-day basis. Examples included CEOs, employers, owners, and directors. Fifteen percent of complainants alleged that they had been bullied by a colleague or co-worker, while just under five percent of cases reported bullying from an employee who held another role within the company-for example, union representatives, human resources personnel, or work health and safety delegates. More specific descriptions of the complainant/perpetrator relationship and exemplar quotes can be found in Table 2 .

Table 2. Position of Alleged Perpetrator in Relation to the Complaint.

\begin{tabular}{|c|c|c|}
\hline $\begin{array}{l}\text { Position of Alleged } \\
\text { Perpetrator }\end{array}$ & $n$ of Cases & Exemplar Quotes \\
\hline Direct supervisor & 165 & $\begin{array}{l}\text { [Manager]'s behaviour in general is unprofessional; I have heard rumours that } \\
\text { he has spread about me. He is secretive about promotional opportunities and } \\
\text { appears to have favourites, I find [Manager] to be abrupt, rude, untruthful and } \\
\text { he rarely seems to know the answers to anything you ask him. } \\
\text { During the second week of May there were times when his face blushed in } \\
\text { anger while screaming to me. He was losing patience. }\end{array}$ \\
\hline
\end{tabular}

CEO received an email of complaint from client; I have not met or committed a time to respond. CEO aggressively questioned why I did not ring him. I repeatedly explained I was away and in hospital. He continued the line of questioning as to who made the commitment-I did not know. He did not

Higher level manager

41

Peer or subordinate

35

Other roles (HR, WHS/Union Rep) relent, and I became upset. He then demanded a resolution meeting the next day. He demanded I apologise, or I receive a letter of warning.

When I have tried to discuss with the Director of Nursing, she has made which effect how I perform my work role-decisions made without my consent or consultation, she either avoids me, or speaks down to me telling me I have no idea and that the decision she has made is reasonable. She is rigid and her decisions are non-negotiable.

[Perpetrators] and select others started having pizza on a Friday for lunch and they would come in and eat it in the office in front of me (I was never asked

whether I wanted to join in).
Since that initial incident most of my colleagues, led by [Colleague], have deliberately excluded me from the normal workplace interactions and activities by ignoring my initial greetings (e.g., good morning, hi mate etc.), going to smoko without me, ceasing conversations when I approach the group, acting as though I am invisible.

There have been numerous occasions where [Perpetrator] has used his influence and position as Union Representative to bully me. [Perpetrator] has threatened management with industrial action, if management allow me to work in the control room even though I am fully qualified and deemed competent to do so.

Ever since I started in marination, [Perpetrator], [Perpetrator], [Perpetrator],

[Perpetrator] and [Perpetrator] and just recently [Perpetrator] have been

Multiple Persons

(not specified)
$10 *$

harassing every day as soon as we are in the factory. They all sit together and [expletive] together. You can tell they are talking about you because they keep turning around or looking over her shoulder giving daggers at you or sometimes you can hear some of what they say.

\footnotetext{
Company/Management increasing expectation and workload.
}

In general I feel this management has worked subversively, gradually 
In 137 cases (out of a possible 174 with sufficient information), the person to whom they initially reported their experience of bullying to internally was recorded. Exemplar quotes and a breakdown of the roles of the reporting person are detailed in Table 3. Complainants were most likely to report bullying their grievance to a direct supervisory figure, while nearly one in three complaints were lodged with a person holding a health and safetyrelated role within the company (e.g., WHS/HR/Union Representative). Nearly one in six complainants sought out an indirect or higher-level superior to lodge their complaint, including the CEO, a board member, or director. A small percentage of complainants specified that they could not make a complaint in their organization, either because they were not sure of the process for reporting internally, or because the alleged perpetrator was the assigned reporting person:

Table 3. Position of the Person Who the Bullying Was Reported to Internally.

\begin{tabular}{|c|c|c|c|}
\hline & & $n$ of People & Exemplar Quotes \\
\hline $\begin{array}{l}\text { Direct Relationship } \\
\text { (Line supervisor) }\end{array}$ & $\begin{array}{c}\text { Manager (Assistant, Café, Centre, Factory, Line, } \\
\text { Maintenance, Practice, Principal, Operations, } \\
\text { Regional, Site, State, Store) } \\
\text { Employer/Boss } \\
\text { Management } \\
\text { Supervisor (Agency, Safety) }\end{array}$ & $\begin{array}{l}34 \\
9 \\
5 \\
5\end{array}$ & $\begin{array}{c}\text { I made an appointment with the Principal-told him it was a } \\
\text { formal complaint and asked him to act on it. } \\
\text { Feeling embarrassed, I talked to my boss and told him what } \\
\text { has happened and what has been said. He said that we will } \\
\text { have a meeting involving the people. Meeting never } \\
\text { happened and got avoided. }\end{array}$ \\
\hline $\begin{array}{l}\text { Indirect Relationship } \\
\text { (Higher-order manager) }\end{array}$ & $\begin{array}{c}\text { Director(s) } \\
\text { (Acting, Assistant, Executive, Nursing) } \\
\text { CEO/Chairman/Board } \\
\text { Owner(s) }\end{array}$ & $\begin{array}{c}10 \\
15 \\
3\end{array}$ & $\begin{array}{l}\text { I sent a letter of complaint to the CEO. } \\
\text { I sent an email to [Director] again with my concerns of the } \\
\text { treatment I was receiving from [Perpetrator], that he was } \\
\text { totally ignoring me and would speak the girls then ask them } \\
\text { to pass it on to me. Again, no reply. }\end{array}$ \\
\hline Other Roles & $\begin{array}{c}\text { HR (Department, Director, Manager, } \\
\text { Representative, Leader) } \\
\text { Perpetrator (Directly) } \\
\text { OHS (Manager, Officer, Representative) } \\
\text { Colleague } \\
\text { Union Representative }\end{array}$ & $\begin{array}{l}39 \\
9 \\
6 \\
1 \\
1\end{array}$ & $\begin{array}{l}\text { The following week I reported this to HR who were } \\
\text { unsupportive, and I was even asked "what did you do to } \\
\text { bring this on?" } \\
\text { I immediately brought this to the attention of my onsite } \\
\text { union representative. }\end{array}$ \\
\hline
\end{tabular}

NOTE: In 79 cases, the position of the person who the bullying was reported to internally could not be coded, as no internal complaint was lodged. In 63 cases, the position of the person who the bullying was reported to internally was not disclosed.

"I made a complaint about how bad things were in [Location] to management only to be told that I'm not to go above [Perpetrator] again. I get a feeling of hopelessness thinking that how do I make a complaint about my bullier to the bullier himself?"

Data regarding the method in which the complaint was submitted were also coded (see Table 4 for an overview of the methods). Complaints about workplace bullying were commonly made verbally $(n=38)$, including a small percentage who confronted the perpetrator directly:

"I confronted [Perpetrator]—who denied it—until I explained I watched her on the camera."

A further 95 records were identified where complaints were lodged via hand-written or electronic mediums, including telephone conversations, formal letters, and emails. Many complainants noted that their complaint went unacknowledged:

"I brought my side to the attention of [President] in an email but it was never acknowledged."

A small number of complainants followed their organization's official procedure with an incident report form, grievance system, or workplace bullying request $(n=5)$. There were no cases that mentioned an online or anonymous reporting system, nor the services of a specialised grievance officer. 
Table 4. Method of Submitting Complaint Internally.

\begin{tabular}{|c|c|c|}
\hline Complaint Mechanism & $n$ of Cases & Exemplar Quotes \\
\hline Verbal Discussion/Complaint & 38 & $\begin{array}{l}\text { I then made a complaint to the operating manager regarding my } \\
\text { manager's appalling behaviour, but he virtually laughed in my face but } \\
\text { stated he would talk to [Perpetrator]. }\end{array}$ \\
\hline Email & 32 & $\begin{array}{l}\text { On or about [Date], the applicant informed his manager via email of the } \\
\text { events that had taken place and the ongoing implications to his welfare. }\end{array}$ \\
\hline Letter & 31 & $\begin{array}{l}\text { Sent a letter of complaint to [Manager] with above incidences, nothing } \\
\text { was done. }\end{array}$ \\
\hline Formal Complaint & 20 & $\begin{array}{l}\text { My two formal complaints in writing were not handled per the } \\
\text { [Organizations]'s policies and procedures. }\end{array}$ \\
\hline Phone Call & 12 & $\begin{array}{l}\text { I called and reported to [Person], one of the managers, and he arranged a } \\
\text { meeting for [Date]. When I went to [Location] to meet him, [Manager] was } \\
\text { not there. I was told he was sick. }\end{array}$ \\
\hline Meeting & 5 & $\begin{array}{c}\text { A recent meeting with [Manager] on this matter was on [Date] in person } \\
\text { where I requested [Manager] to ask [Perpetrator] to cease his bullying and } \\
\text { harassing behaviour towards me where [Manager] told me I had to accept } \\
\text { that it the way [Perpetrator] is. }\end{array}$ \\
\hline Grievance Form & 3 & $\begin{array}{l}\text { The only formal mechanism available to do so by my employer is } \\
\text { "Administrative Grievance Procedure". There is no "bullying" } \\
\text { complaints mechanism. }\end{array}$ \\
\hline Incident Report & 2 & $\begin{array}{l}\text { I attempted to mitigate my situation by lodging an incident report which } \\
\text { went to an external investigator and was not sustained }\end{array}$ \\
\hline
\end{tabular}

NOTE: In 68 cases, method of complaint submission was not applicable, as no internal complaint was lodged. In 65 cases, the method of complaint submission was not disclosed in the case files. In 7 cases, there was confirmation of no internal complaint being lodged; hence, there was no method of complaint submission.

\subsection{Manifestation of Organizational Justice in Internal Workplace Bullying Complaints and Investigations}

When lodging a request for investigation with SafeWork SA, complainants were asked to provide a detailed written account of the bullying situation in their workplace, including their original complaint and what action (or inaction) has already been implemented or considered by the organization. Each evaluation of the complaint and/or investigation process made by complainants was recorded and coded to types of violations to organisational justice (i.e., distributive, procedural, interpersonal, and informational) [12]. An overview of the manifestation of organisational justice violations across the cases is shown in Table 5. In evaluating the internal complaint process, complainants were most likely to note issues with procedural justice (i.e., lack of sincerity, action, and communication), while internal investigations triggered perceived violations to distributive justice (i.e., not substantiating complaints, inappropriate action).

Table 5. Percentage of Cases Represented by Violations to Justice Type.

\begin{tabular}{|c|c|c|c|c|c|}
\hline Process & $\begin{array}{c}\text { No. of Cases (with } \\
\text { Sufficient Information) }\end{array}$ & Justice Type & $\begin{array}{c}\text { No. of } \\
\text { Evaluations }\end{array}$ & No. of Cases & $\begin{array}{l}\text { Percentage of Cases Where } \\
\text { Justice Type Manifested }\end{array}$ \\
\hline \multirow{4}{*}{ Complaints } & \multirow{4}{*}{163} & Procedural & 130 & 124 & $76 \%$ \\
\hline & & Distributive & 67 & 65 & $39 \%$ \\
\hline & & Interpersonal & 39 & 39 & $24 \%$ \\
\hline & & Informational & 24 & 24 & $15 \%$ \\
\hline \multirow{4}{*}{ Investigations } & \multirow{4}{*}{75} & Distributive & 55 & 52 & $69 \%$ \\
\hline & & Procedural & 46 & 38 & $50 \%$ \\
\hline & & Interpersonal & 16 & 13 & $17 \%$ \\
\hline & & Informational & 13 & 13 & $17 \%$ \\
\hline
\end{tabular}


Table 6 overviews (in detail) the manifestation of organizational justice in workplace bullying complaints process. Procedural justice was regularly threatened where due process was not followed, i.e., where there was no response or action from the organization following submission of the complaint (which also triggered perceptions of poor distributive justice), where the complaint was not properly acknowledged or escalated, where there was perceived pressure to withdraw the complaint, and when confidentiality of the complaint process was breached. Similarly, a lack of support from the organization activated perceptions of diminished interpersonal justice, stemming from perceived pressure to withdraw the complaint and/or accept inappropriate actions resulting from the complaint process. We explored the potential for a relationship between perceptions of organisational justice manifestation to perpetrator type and to investigator role but did not observe any significant associations.

Table 6. Triggers of Justice Reactions in the Internal Complaint Process.

\begin{tabular}{|c|c|c|c|c|}
\hline & Evaluation & Justice Type & $n$ of Evaluations & Exemplar Quotes \\
\hline \multirow{4}{*}{$\begin{array}{l}\text { Complaint was } \\
\text { lodged internally }\end{array}$} & $\begin{array}{l}\text { The organization took no action as a } \\
\text { result of a complaint being lodged }\end{array}$ & Procedural; Distributive & 36 & $\begin{array}{c}\text { Tried to report this to [Manager] on } \\
\text { several occasions only to be told to "Get } \\
\text { used to it, that's just the way } \\
\text { [Perpetrator] is" } \\
\text { I have bought this up with [Manager] } \\
\text { when trying to get opportunity to defend } \\
\text { myself. I have seen or heard no action } \\
\text { from it. }\end{array}$ \\
\hline & $\begin{array}{l}\text { Complainant felt their grievance was } \\
\text { not taken seriously } \\
\text { (e.g., told to ignore behaviour, nothing } \\
\text { could be done, accept behaviour) }\end{array}$ & Procedural & 25 & $\begin{array}{l}\text { Union dismissed my complaint as trivial } \\
\text { and took no action whatsoever } \\
\text { It does not matter how often I complain } \\
\text { the leading hand and supervisor do not } \\
\text { listen or believe me when I tell them. }\end{array}$ \\
\hline & $\begin{array}{l}\text { Complainant did not receive a } \\
\text { response following submission } \\
\text { of complaint }\end{array}$ & Procedural; informational & 24 & $\begin{array}{c}\text { My final complaint has not been } \\
\text { acknowledged despite my repeated } \\
\text { follow up emails and [Organization]'s } \\
\text { policy that management will thoroughly } \\
\text { and promptly investigate every } \\
\text { reported incident } \\
\text { I am lodging this complaint because the } \\
\text { grievance process I initiated with my } \\
\text { employer on [Date] has been ignored. }\end{array}$ \\
\hline & $\begin{array}{c}\text { Inappropriate action was taken as a } \\
\text { result of complaint } \\
\text { (e.g., hours reduced, supported } \\
\text { perpetrator, not handled per policy, } \\
\text { complainant moved to different area of } \\
\text { organisation, threatened complainant) }\end{array}$ & $\begin{array}{l}\text { Distributive; procedural; } \\
\quad \text { interpersonal }\end{array}$ & 21 & $\begin{array}{l}\text { After bringing complaints forward I was } \\
\text { blamed for this and then they tried to } \\
\text { transfer me to a different store. } \\
\text { My complaint against my manager has } \\
\text { not been dealt with properly }\end{array}$ \\
\hline \multirow{5}{*}{$\begin{array}{l}\text { Complaint was } \\
\text { lodged internally }\end{array}$} & $\begin{array}{l}\text { Advised to meet with perpetrator/Sort } \\
\text { it out themselves/Go to SWSA }\end{array}$ & Procedural; interpersonal & 8 & $\begin{array}{l}\text { I approached the Head of ... over } 6 \mathrm{mths} \\
\text { ago in regards to the above and was told } \\
\text { to "sort it out between yourselves" }\end{array}$ \\
\hline & $\begin{array}{c}\text { Complainant felt scared/unsupported } \\
\text { during process }\end{array}$ & Interpersonal & 6 & $\begin{array}{l}\text { I have suffered anxiety since my } \\
\text { employment at [Organization], to the } \\
\text { point where I was too fearful to take } \\
\text { further action. [Perpetrator]'s behaviour } \\
\text { was unlike anything I have ever } \\
\text { experienced in the workplace and I } \\
\text { would not wish this experience } \\
\text { upon anyone. }\end{array}$ \\
\hline & $\begin{array}{l}\text { Complainant reported that } \\
\text { confidentiality was breached }\end{array}$ & Procedural & 5 & $\begin{array}{l}\text { You should note that the complaint letter } \\
\text { my partner wrote to [HR Manager] was } \\
\text { then forwarded to the [Perpetrator] and } \\
\text { [Perpetrator], two of the people the } \\
\text { complaint letter was about... she said } \\
\text { that [HR Manger] was within his rights to } \\
\text { do this as they are the managers involved } \\
\text { with my work cover claim. }\end{array}$ \\
\hline & $\begin{array}{l}\text { Organisation denied receipt of } \\
\text { complaint/presence of bullying }\end{array}$ & Distributive; interpersonal & 4 & $\begin{array}{c}\text { [Company] is unwilling to retrain or } \\
\text { acknowledge any victimisation occurred } \\
\text { on site }\end{array}$ \\
\hline & $\begin{array}{l}\text { Bullying behaviour continued even } \\
\text { after action taken }\end{array}$ & Distributive & 3 & $\begin{array}{l}\text { I have raised my issues with } \\
\text { management on numerous occasions } \\
\text { [Dates] even though in meetings with } \\
\text { management I was assured that serious } \\
\text { steps will be taken to resolve the issue } \\
\text { but still the problem exists }\end{array}$ \\
\hline
\end{tabular}


Table 6. Cont

\begin{tabular}{|c|c|c|c|c|}
\hline & Evaluation & Justice Type & $n$ of Evaluations & Exemplar Quotes \\
\hline \multirow{4}{*}{$\begin{array}{l}\text { Complaint was } \\
\text { not lodged }\end{array}$} & $\begin{array}{l}\text { Lack of trust/confidence in } \\
\text { investigator or investigative system }\end{array}$ & Procedural & 6 & $\begin{array}{l}\text { I did not go to [Higher body] as I am one } \\
\text { on a list of people and feel nothing comes } \\
\text { of it }\end{array}$ \\
\hline & $\begin{array}{l}\text { Did not feel there was a valid internal } \\
\text { reporting mechanism }\end{array}$ & Procedural & 5 & $\begin{array}{l}\text { Since I was harassed by the HR } \\
\text { representative and my department } \\
\text { manager I felt as though I had nowhere } \\
\text { to turn. Who was I meant to report to? }\end{array}$ \\
\hline & Felt no action would be taken & Distributive & 2 & $\begin{array}{l}\text { [Complainant] explains he did not raise } \\
\text { the issues with [Company] as he feels } \\
\text { nothing will happen }\end{array}$ \\
\hline & Fear of consequences & Distributive & 1 & $\begin{array}{l}\text { I have no confidence in my workplace's } \\
\text { system of dealing with this issue and feel } \\
\text { that by taking it to them it may threaten } \\
\text { my employment there }\end{array}$ \\
\hline
\end{tabular}

NOTE: In 68 cases, there was no evidence of internal complaint being submitted. In 43 cases, the outcome of the complaint was not disclosed (in case files). In 15 cases, no complaint was not lodged (confirmed) (no reason given).

In addition, Table 7 overviews bullying complainants' evaluations of the internal investigation process and corresponding threats to organizational justice. Similar to the complaint process, a failure to follow due process threatened perceived procedural justice, expressed through difficulty in initiating investigations, continued exposure to bullying behaviour following a completed investigation, and investigations that were biased, incomplete, untimely, and fraudulent in nature (the latter two of which also threatened informational justice). Poor outcomes following the investigation (such as a failure to validate claims of bullying, continued exposure to workplace bullying, or reallocation to a different area of the organization) jeopardised distributive justice.

Table 7. Triggers of Justice Reactions in the Internal Investigation Process.

\begin{tabular}{|c|c|c|c|}
\hline Evaluation & Justice Type & $n$ of Evaluations & Exemplar Quotes \\
\hline $\begin{array}{l}\text { Organization did not substantiate } \\
\text { claims of bullying } \\
\text { following investigation }\end{array}$ & Distributive & 17 & $\begin{array}{l}\text { I attempted to mitigate my situation by lodging a } \\
\text { formal complaint of bullying which went to an } \\
\text { external investigator and was not sustained. The } \\
\text { Executive Director told me I could lodge an } \\
\text { application for internal review which was } \\
\text { subsequently withdrawn by Workforce Division } \\
\text { and denied under Section } 61 \text { \& } 62 \text { of the Public } \\
\text { Sector Act } 2009 \text {. } \\
\text { As was discussed during our final meeting on } \\
\text { [Date] the outcome of the investigation was that } \\
\text { my complaint of bullying and harassment against } \\
\text { [Perpetrator] was not substantiated }\end{array}$ \\
\hline $\begin{array}{l}\text { Inappropriate action } \\
\text { (e.g., moved to different department, } \\
\text { complainant blamed for behaviour, } \\
\text { accused of bullying themselves, } \\
\text { position made redundant, attributed } \\
\text { claims to personality clashes) }\end{array}$ & Distributive; procedural; interpersonal & 16 & $\begin{array}{l}\text { My treatment by [OHS/HR manager] was very } \\
\text { one sided in which representation in my defence } \\
\text { of sacking was denied. I could not talk back to } \\
\text { defend myself as he just would not listen or } \\
\text { entertain my defence. } \\
\text { In addition, [Complainant], and the other two } \\
\text { complainants consider that other employees who } \\
\text { were also of the same party as [Perpetrator], had } \\
\text { not been dealt with at all. } \\
\text { [Superior] objected to this proposal and had to } \\
\text { point out that simply moving [Perpetrator] to } \\
\text { another department was in no way a satisfactory } \\
\text { way of dealing with such a serious complaint. } \\
\text { Why should the victim have to be taken out of her } \\
\text { professional position, and at this stage of her } \\
\text { career, learn another role? }\end{array}$ \\
\hline $\begin{array}{l}\text { Investigation was not completed in a } \\
\text { timely matter/per company policy } \\
\text { (e.g., not all witnesses investigated, } \\
\text { did not adhere to policy, protective of } \\
\text { perpetrator, no action taken based } \\
\text { on findings) }\end{array}$ & Procedural; informational & 13 & $\begin{array}{l}\text { I complained numerous times to [Supervisor] } \\
\text { verbally. My two formal complaints in writing } \\
\text { were not handled per the schools' policies and } \\
\text { procedures. } \\
\text { At no stage has [Organization] or [Chairman] } \\
\text { followed Policy or Procedures related to the } \\
\text { following (which also forms part of the grievance } \\
\text { I made to my employer). }\end{array}$ \\
\hline $\begin{array}{l}\text { No outcome/response } \\
\text { from investigation }\end{array}$ & Procedural & 10 & $\begin{array}{l}\text { The outcome of the internal investigation } \\
\text { provided me with no outcome or resolution. } \\
\text { An investigation was instigated but no outcome } \\
\text { noted in file. }\end{array}$ \\
\hline
\end{tabular}


Table 7. Cont

\begin{tabular}{|c|c|c|c|}
\hline Evaluation & Justice Type & $n$ of Evaluations & Exemplar Quotes \\
\hline $\begin{array}{l}\text { Bullying continued } \\
\text { despite investigation }\end{array}$ & Distributive & 9 & $\begin{array}{l}\text { I have followed [Company]'s policies and } \\
\text { procedures in regard to having these matters } \\
\text { addressed internally but the situation has } \\
\text { continued over a sustained period of time. }\end{array}$ \\
\hline $\begin{array}{l}\text { Appropriate action taken } \\
\text { (e.g., mediation, perpetrators } \\
\text { retrained or disciplined) }\end{array}$ & Distributive; procedural & 7 & $\begin{array}{l}\text { Investigation revealed that there was a } \\
\text { breakdown in communication and the working } \\
\text { relationship. [Company] has sent expectation } \\
\text { letters to all managers and to the alleged bully. } \\
\text { [Company] is supplying further coaching to } \\
\text { managers and alleged bully. }\end{array}$ \\
\hline $\begin{array}{l}\text { Investigation occurred; } \\
\text { claims substantiated }\end{array}$ & Distributive & 6 & Claims of bullying were substantiated by SWSA. \\
\hline
\end{tabular}

NOTE: In 185 cases, there was no evidence of an internal investigation having occurred. In 27 cases, an investigation occurred, but no record of the outcome was disclosed in file. In 2 cases, an investigation did not occur before complainant lodged a request for investigation with SafeWork SA.

\section{Discussion}

In this study, we analysed 289 real-life workplace bullying complaints lodged with a peak state regulatory body in order to understand how justice reactions are triggered in the internal bullying complaint and investigation process. In examining complaints that were, by definition, unable to be resolved internally, our sample comprised many observations regarding the manifestation of organizational injustice in the way that bullying situations are handled within organizations. We found evidence that all four types of justicedistributive, procedural, interpersonal, and informational-play a role in the way that targets of bullying appraise the internal processes for lodging and investigating complaints. In other words, in situations where distributive justice is not upheld (such as for the complaints in our sample that were escalated outside of the organization), the way in which information is gathered and decisions are made (procedural), the way in which the parties are treated (interpersonal), and the timeliness and validity of explanations provided (informational) are all cited by complainants as key factors in their decision to escalate the complaint.

\subsection{Contribution to Knowledge}

In making a complaint, targets of bullying are arguably attempting to seek fair resolution of an unfair situation. Based on our findings, both the processes involved, and the outcomes of the bullying complaint and investigation procedure contain significant triggers of justice reactions that are important to understand. Traditionally, the organizational justice literature has emphasised the concepts of equity, equality, and need as a foundation for distributive justice perceptions. Equity relates to the ratio of work inputs and outputs, for example, the distribution of rewards according to individual effort, often in comparison with others. Equality is defined as equal access to resources and/or equal distribution of rewards to all members of a group regardless of individuals' contributions. Need reflects favourable allocation of rewards according to individuals' specific needs [32,48]. In our study, complainants experienced lapses in all three concepts of distributive justice-namely, inequitable investigation practices (e.g., a failure to investigate all perpetrators), inequitable processes (e.g., a lack of organisational response to bullying complaints), and poor need allocation (i.e., removal or termination of the complainant instead of the perpetrator).

In terms of procedural justice, procedures should be consistent across persons and time (consistency), based on valid information (accuracy), neutral and impartial (bias suppression), allow for a mechanism to appeal the procedure and correct poor decisions (correctability), uphold moral and ethical values (ethicality), and be representative of the concerns and needs of all persons affected (representativeness) [49,50]. In our study, threats to procedure justice were noted, whereby investigations were not conducted in a valid (i.e., failure to investigate all perpetrators or investigate according to company policy), impartial (i.e., biased investigations and pressure was placed on complainants to withdraw their grievance), or ethical manner (i.e., breaches in confidentiality). Additionally, there were few 
courses of correctability for poor decisions (i.e., being investigated for bullying themselves, transfers, or no action taken upon receipt of complaint or conclusion of investigation) and no references to representativeness or consistency.

Interpersonal justice, or the importance of receiving polite, dignified, respectful, and proper interpersonal treatment [19] with sensitivity [51] was highlighted in the current study, where complainants felt scared, unsupported, and pressured during the investigative process and deeply unsatisfied with the outcome in many cases (including where they themselves were disciplined or transferred throughout the company).

In terms of information justice, an authority figure is expected to be candid [19] and provide thorough, reasonable, timely, and specific information [31]. This surfaced in our findings by virtue of untimely investigations and failures to adhere to company policy for dispute resolutions, although it is likely that many complainants failed to acquire the information that they required to further their case.

Together, our findings regarding the manifestation of justice in the complaint and investigation process reveal a new element in how workplace bullying complainants articulate their experience of the complaint's investigation. Despite the perception of having been exposed to unfair (bullying) treatment, targets of bullying who make a complaint expect (or hope) to be able to resolve that treatment in a fair way with the support of their employer organization. When they are unable to do so, complainants, who already hold little to no control over their external environment, experience diminished wellbeing and commitment to the organisation [52]. According to our findings, complainants seem to seek a sense of validation. It is possible that, for targets of bullying, validation is a core aspect of the way in which an organization responds to bullying. This was evident in evaluations of the complaint and investigation process that highlighted a desire to be taken seriously, to be acknowledged in an appropriate and timely manner, to be treated with dignity and respect, and ultimately, for their claim of bullying to be substantiated (which only occurred in 2 out of 280 cases).

Workplace bullying is a type of stressor that functions as a threat to the self [53] interfering with the basic need for positive regard by others [54]. In this way, seeking validation through the complaint and investigation process may have the intended function of restoring the sense of self that was diminished through ongoing bullying exposure. Extrapolating from our data, it may be that complainants see the process and the outcomes of the complaint investigation as having the potential to re-establish a lost sense of positive regard; when this does not happen, it stands out as being very important to complainants. The role of the workplace bulling complaint and investigation process in validating the sense of self and positive regard is an interesting phenomenon hinted at by our data that we believe would be worthwhile exploring in future research.

\subsection{Practical Implications}

Our findings suggest that bullying complainants covet a validated sense of self in the way that the complaint is handled and investigated. This is not always possible in terms of the outcome of a complaint/investigation. It is, however, a worthy and more achievable goal in terms of the process through which bullying complaints are handled. Indeed, safeguarding procedural and interpersonal justice will reduce the stress associated with making a complaint even if the outcome is not what the complainant wants [14].

Although not all claims of bullying will (or should) be substantiated, efforts should made to reduce distributive injustice. At the heart of this lies a conceptual shift in how organisations view (and manage) bullying and other forms of harmful interpersonal behaviour. Specifically, all negative workplace behaviours (even those that do not meet the legal or official definition of workplace bullying) should be acknowledged, recorded, and addressed. At its core, workplace bullying is an organisational problem that manifests as negative interactions between two or more co-workers, and even minor forms of workplace bullying (i.e., incivility) pose a significant risk to employee health and safety [55]. Taking care to capture all contextual and nuanced facets of the bullying complaints provides a rich 
source of data regarding the underlying contributors to bullying specific to that workplace. From this, improvements can be made the work design, coordination, and management of work, improving outcomes for employees, regardless of whether the claim of bullying is substantiated.

The most valuable conduit to re-validating employees' sense of self lies in improving the processes, policies and investigative structures that contribute to procedural, interpersonal, and informational justice. Organisations should declare a clear commitment to protect employees from psychological risks (such as workplace bullying) but avoid catch-all phrases such as 'zero tolerance', as it is not feasible 100\% of the time [56] and thus may threaten procedural justice if not properly enforced.

Ideally, workplace behavioural policies should be informative and direct, incorporating definitions and examples of what bullying is and is not (updated regularly to reflect new forms of bullying behaviour, e.g., cyberbullying), references to legislation and regulations (where available), a clear list of personnel who should be contacted if bullying occurs (including personnel that do not directly oversee the complainant/target) and the responsibilities and requirements of management and employees, including who will conduct investigations if deemed necessary [10], thereby limiting potential threats to informational justice.

Importantly, the internal investigation process (and associated policies) on bullying should not exist just for the sake of meeting state health and safety regulations. The presence of a policy and grievance procedure is futile without adhering to the conditions outlined in it. Each investigation should be treated seriously, by clearly outlining the consequences of bullying others and consulting with all appropriate parties. Responders who rely solely on avoidant or transfer measures of responding to workplace bullying send the message to workers that negative workplace behaviours are not only tolerated, but potentially encouraged, and spark threats to interpersonal justice within complainants.

Optimising the complaint and investigation process through a justice lens also presents an opportunity for novel approaches to complainant validation. Specifically, by focussing on the needs of the harmed (i.e., the bullying targets), and investigating such incidents collaboratively and with a shared decision-making tactic, allows capacity to rebuild trust and encourage employee engagement and development at work [57].

\subsection{Strengths, Limitations and Future Directions}

A key strength of this study lies in the use of richly contextual data-drawing on reallife case data from a large number of self-identified targets of workplace bullying allows researchers to tap into the subjective dimension and sense-making process of this complex issue [58]. Conversely, the dataset is inherently limited by the information available in the SafeWork SA case files. SafeWork SA's primary role is to investigate the transparency and fairness of an organisations' internal investigation process, and to ascertain whether the organisation had policies and procedures in place to minimise the risk of exposure to workplace bullying (in line with Occupational Health and Safety laws). This process did not necessarily include thorough documentation about the actual investigation process (to ensure it is fair and transparent). Consequently, some files provided limited or minimal information about to whom and how complaints were submitted, why the complainant sought outside intervention and how they evaluated the internal investigation process. Accordingly, we risk the omission of other factors that underpin evaluation on complaint and investigation processes that were not documented here. Ideally future studies should collect this information directly (from the organisation).

Additionally, the data presented here is evidentiary of how ineffective investigations play out-however it is imprudent to assume that abstaining from these practices or adopting contradictory actions will yield greater restoration of justice. Academically, evidence of effective internal investigations is limited, as cases that are successfully managed are usually done so informally, in house, and before the problem escalates to the point of formal investigation. Thus, the process and substance of effective complaint and investigation 
procedures remains unclear. Future research should examine the investigation process of organisations that report successful interventive measures (i.e., internal policies and investigation processes), to supplement and contrast information on successful practices to restore justice [59].

In Australia, legislation regarding workplace bullying was harmonised in 2014-one year after the cases in our analysis were finalised. We note that since that time three key pieces of guidance material have been released to guide appropriate intervention and prevention of workplace bullying $[24,60,61]$. Thus, it is possible that a trickledown effect of more effective investigative methods is now in place in these organisations-further research should ascertain the effect of these materials on how investigations are conducted and subsequent perceptions of organisational justice.

Finally, the data in this study does not allow for comparison or rating of the most and least severe forms of organisational justice violation, nor a correlational or causational connection to individual or organisational outcomes. However, such questions can be readily addressed with appropriate sampling and study methodology.

\subsection{Conclusions}

Formal complaints investigation is often a core feature of an organisations' response to workplace bullying. When executed poorly, complainants of workplace bullying may perceive diminished organisational fairness and justice, thereby triggering escalation to an external body for further investigation. In identifying the challenges inherent to effective internal investigation and resolution, we draw attention to key areas of consideration and amendment to the internal investigation process (i.e., improved communication practices between the organisation and complainant(s), fair transparent and timely investigative processes, and greater organisational support for employees who bring grievances to light). The nature and implementation of such processes merit further theoretical and empirical investigation but hold great promise in addressing and reducing occurrences of workplace bullying.

Author Contributions: Conceptualization, A.M.N., M.R.T. and Y.L.; methodology, M.R.T., Y.L. and A.M.N.; software, A.M.N.; validation, M.R.T., Y.L. and A.M.N.; formal analysis, A.M.N.; investigation, A.M.N., M.R.T. and Y.L.; resources, A.M.N. and M.R.T.; data curation, A.M.N.; writing—original draft preparation, A.M.N., Y.L. and M.R.T.; writing—review and editing, A.M.N., M.R.T. and Y.L.; visualization, M.R.T.; supervision, M.R.T.; project administration, A.M.N. and M.R.T.; funding acquisition, M.R.T., Y.L. and A.M.N. All authors have read and agreed to the published version of the manuscript.

Funding: This research was funded by SafeWork SA WHS Commissioned Research Grant, grant name Developing a Workplace Bullying Risk Audit Tool.

Institutional Review Board Statement: The study was conducted according to the guidelines of the Declaration of Helsinki and approved by the Ethics Committee of the University of South Australia (0000034756).

Informed Consent Statement: Participant consent was waived due to the nature of data.

Data Availability Statement: Data can be made available upon request. Please address requests to the corresponding author.

Conflicts of Interest: The authors declare no conflict of interest.

\section{References}

1. Einarsen, S.; Hoel, H.; Zaph, D.; Cooper, C.L. The concept of bullying and harassment at work: The European tradition. In Bulling and Harassment in the Workplace: Developments in Theory, Research and Practice, 2nd ed.; Einarsen, S., Hoel, H., Zaph, D., Cooper, C., Eds.; CRC Press: Boca Raton, FL, USA, 2010; pp. 3-41.

2. Nielsen, M.B.; Matthiesen, S.B.; Einarsen, S. The impact of methodological moderators on prevalence rates of workplace bullying. A meta-analysis. J. Occup. Organ. Psychol. 2010, 83, 955-979. [CrossRef]

3. Nielsen, M.B.; Einarsen, S. Outcomes of exposure to workplace bullying: A meta-analytic review. Work Stress 2012, 26, 309-332. [CrossRef] 
4. Low, K.S.D.; Radhakrishnan, P.; Schneider, K.T.; Rounds, J. The experiences of bystanders of workplace ethnic harassment. J. Appl. Soc. Psychol. 2007, 37, 2261-2297. [CrossRef]

5. Miner-Rubino, K.; Cortina, L.M. Working in a context of hostility toward women: Implications for employees' well-being. J. Occup. Health Psychol. 2004, 9, 107-122. [CrossRef]

6. Hoel, H.; Sheehan, M.J.; Cooper, C.L.; Einarsen, S. Organisational effects of workplace bullying. In Bulling and Harassment in the Workplace: Developments in Theory, Research and Practice, 2nd ed.; Einarsen, S., Hoel, H., Zaph, D., Cooper, C., Eds.; CRC Press: Boca Raton, FL, USA, 2010; pp. 129-148.

7. Høgh, A.; Clausen, T.; Bickmann, L.; Hansen, Å.M.; Conway, P.M.; Baernholdt, M. Consequences of workplace bullying for individuals, organizations and society. In Pathways of Job-Related Negative Behavior; D'Cruz, P., Noronha, E., Baillien, E., Catley, B., Harlos, K., Hogh, A., Eds.; Springer: Singapore, 2021; pp. 177-200.

8. Eriksen, T.L.M.; Hogh, A.; Hansen, Å.M. Long-term consequences of workplace bullying on sickness absence. Labour Econ. 2016, 43, 129-150. [CrossRef]

9. Thompson, N.; Catley, B. Managing workplace bullying complaints: Conceptual influences and the effects of contextual factors. In Dignity and Inclusion at Work; D'Cruz, P., Noronha, E., Caponecchia, C., Escartín, J., Salin, D., Tuckey, M.R., Eds.; Springer Nature: Singapore, 2018; Volume 3, pp. 109-146.

10. Vartia, M.; Leka, S. Interventions for the prevention and management of bullying at work. In Bullying and Harassment in the Workplace: Developments in Theory, Research, and Practice, 2nd ed.; Einarsen, S., Hoel, H., Zapf, D., Cooper, C., Eds.; CRC Press: Boca Raton, FL, USA, 2011; pp. 359-380.

11. Hoel, H.; Einarsen, S. Investigating complaints of bullying and harassment. In Bullying and Harassment in the Workplace: Developments in Theory, Research and Practice, 3rd ed.; Einarsen, S., Hoel, H., Zapf, D., Cooper, C., Eds.; CRC Press: Boca Raton, FL, USA, 2020; pp. 541-562.

12. Greenberg, J. Organizational justice: Yesterday, today, and tomorrow. J. Manag. 1990, 16, 399-432. [CrossRef]

13. Cropanzano, R.; Byrne, Z.S.; Bobocel, D.R.; Rupp, D.E. Moral virtues, fairness heuristics, social entities, and other denizens of organizational justice. J. Vocat. Behav. 2001, 58, 164-209. [CrossRef]

14. Greenberg, J. Stress fairness to fare no stress: Managing workplace stress by promoting organizational justice. Organ. Dyn. 2004, 33, 352-365. [CrossRef]

15. Eisele, P. Organizational justice and workplace bullying: Validating two instruments and testing their joined relation with wellbeing. Int. J. Bus. Soc. Sci. 2016, 7, 167-176.

16. Samsudin, E.Z.; Isahak, M.; Rampal, S.; Rosnah, I.; Zakaria, M.I. Organisational antecedents of workplace victimisation: The role of organisational climate, culture, leadership, support, and justice in predicting junior doctors' exposure to bullying at work. Int. J. Health Plan. Manag. 2020, 35, 346-367. [CrossRef]

17. Seyrek, H.; Ekici, D. Nurses' Perception of organisational justice and its effect on bullying behaviour in the hospitals of turkey. Hosp. Pract. Res. 2017, 2, 72-78. [CrossRef]

18. Hsu, F.-S.; Liu, Y.-A.; Tsaur, S.-H. The impact of workplace bullying on hotel employees' well-being: Do organizational justice and friendship matter? Int. J. Contemp. Hosp. Manag. 2019, 31, 1702-1719. [CrossRef]

19. Bies, R.J.; Moag, J.S. Interactional justice: Communication criteria for fairness. In Research on Negotiation in Organizations; Sheppard, B., Ed.; JAI Press: Greenwich, CT, USA, 1986; pp. 43-55.

20. Clay-Warner, J.; Reynolds, J.; Roman, P. Organizational justice and job satisfaction: A test of three competing models. Soc. Justice Res. 2005, 18, 391-409. [CrossRef]

21. Rayner, C. Workplace bullying: Consequences, precursors, and best practices. In Proceedings of the Academy of Management Meeting 2005, Honolulu, HI, USA, 5-10 August 2005.

22. Song, C.; Wang, G.; Wu, H. Frequency and barriers of reporting workplace violence in nurses: An online survey in China. Int. J. Nurs. Sci. 2021, 8, 65-70. [CrossRef] [PubMed]

23. Burr, C.; Wyatt, A. Investigation of workplace bullying and harassment complaints. In Dignity and Inclusion at Work; D'Cruz, P., Noronha, E., Caponecchia, C., Escartín, J., Salin, D., Tuckey, M.R., Eds.; Springer Nature: Singapore, 2021; pp. 147-180.

24. Safe Work Australia. Guide for Preventing and Responding to Workplace Bullying. 2016. Available online: https://www. safeworkaustralia.gov.au/doc/guide-preventing-and-responding-workplace-bullying (accessed on 21 May 2021).

25. Catley, B.; Blackwood, K.; Forsyth, D.; Tappin, D.C. Workplace bullying complaints: Lessons for "good HR practice". Personn. Rev. 2017, 46, 100-114. [CrossRef]

26. Hoel, H.; Einarsen, S. Investigating complaints of bullying and harassment. In Bulling and Harassment in the Workplace: Developments in Theory, Research and Practice, 2nd ed.; Einarsen, S., Hoel, H., Zaph, D., Cooper, C., Eds.; CRC Press: Boca Raton, FL, USA, 2010; pp. 341-358.

27. Lind, E.A. Fairness heuristic theory: Justice judgments as pivotal cognitions in organizational relations. In Advances in Organizational Justice; Greenberg, J., Cropanzano, R., Eds.; Stanford University Press: Stanford, CA, USA, 2001; pp. 56-88.

28. Van den Bos, K. Fairness heuristic theory: Assessing the information to which people are reacting has a pivotal role in understanding organizational justice. In Theoretical and Cultural Perspectives on Organizational Justice; Gilliland, S., Steiner, D., Skarlicki, D., Eds.; Information Age: Greenwich, CT, USA, 2001; pp. 63-84. 
29. Van den Bos, K.; Lind, E.A.; Wilke, H.A.M. The psychology of procedural justice and distributive justice viewed from the perspective of fairness heuristic theory. In Justice in the workplace: From Theory to Practice; Cropanzano, R., Ed.; Erlbaum: Mahwah, NJ, USA, 2001; Volume 2, pp. 49-66.

30. Rodell, J.B.; Colquitt, J.A. Looking ahead in times of uncertainty: The role of anticipatory justice in an organizational change context. J. Appl. Psychol. 2009, 94, 989-1002. [CrossRef]

31. Colquitt, J.A. On the dimensionality of organizational justice: A construct validation of a measure. J. Appl. Psychol. 2001, 86, 386-400. [CrossRef]

32. Leventhal, G.S. The distribution of rewards and resources in groups and organizations. In Advances in Experimental Social Psychology; Berkowitz, L., Walster, W., Eds.; Academic Press: New York, NY, USA, 1976; Volume 9, pp. 91-131.

33. Jenkins, M.; Winefield, H.; Sarris, A. Perceptions of unfairness in the management of bullying complaints: Exploring the consequences. Int. J. Bus. Adm. 2013, 4, 16-25. [CrossRef]

34. Lam, S.S.K.; Schaubroeck, J.; Aryee, S. Relationship between organizational justice and employee work outcomes: A cross-national study. J. Organ. Behav. 2001, 23,1-18. [CrossRef]

35. Folger, R.G.; Cropanzano, R. Organizational Justice and Human Resource Management; Sage: Thousand Oaks, CA, USA, 1998; Volume 7.

36. Folger, R.G.; Rosenfield, D.; Grove, J.; Corkran, L. Effects of "voice" and peer opinions on responses to inequity. J. Personal. Soc. Psychol. 1979, 37, 2253. [CrossRef]

37. Thornhill, A.; Saunders, M. Exploring employees' reactions to strategic change over time: The utilisation of an organizational justice perspective. Iran. J. Manag. 2003, 24, 66-86.

38. Van den Bos, K.; Lind, E.A.; Vermunt, R.; Wilke, H.A. How do I judge my outcome when I do not know the outcome of others? The psychology of the fair process effect. J. Personal. Soc. Psychol. 1997, 72, 1034-1046. [CrossRef]

39. Shapiro, D.L.; Kirkman, B. Employees' reaction to the change to work teams: The influence of "anticipatory" injustice. J. Organ. Chang. Manag. 1999, 12, 51-67. [CrossRef]

40. Shapiro, D.L.; Kirkman, B.L. Anticipatory injustice: The consequences of expecting injustice in the workplace. In Advances in Organizational Justice; Greenberg, J., Cropanzano, R., Eds.; New Lexington: Lexington, MA, USA, 2001; pp. 152-178.

41. Rudman, L.A.; Borgida, E.; Robertson, B.A. Suffering in silence: Procedural justice versus gender socialization issues in university sexual harassment grievence procedures. Basic Appl. Soc. Psychol. 1995, 17, 519-541. [CrossRef]

42. Fox, S.; Stallworth, L.E. Building a framework for two internal organizational approaches to resolving and preventing workplace bullying: Alternative dispute resolution and training. Consult. Psychol. J. Pract. Res. 2009, 61, 220-241. [CrossRef]

43. Hogler, R.L.; Frame, J.H.; Thornton, G. Workplace sexual harassment law: An empirical analysis of organizational justice and legal policy. J. Manag. Issues 2002, 14, 234-250.

44. Guglielmi, D.; Mazzetti, G.; Villano, P.; Topa Cantisan, G. The impact of perceived effort-reward imbalance on workplace bullying: Also a matter of organizational identification. Psychol. Health Med. 2018, 23, 511-516. [CrossRef]

45. Jenkins, M.; Winefield, H.; Sarris, A. Consequences of being accused of workplace bullying: An exploratory study. Int. J. Work Health Manag. 2011, 4, 33-47. [CrossRef]

46. Cowan, R.L. "Rocking the boat" and "Continuing to fight": Un/productive justice episodes and the problem of workplace bullying. Hum. Commun. 2009, 12, 283-301.

47. Braun, V.; Clarke, V. Using thematic analysis in psychology. Qual. Res. Psychol. 2006, 3, 77-101. [CrossRef]

48. Deutsch, M. Distributive Justice; Yale University Press: New Haven, CT, USA, 1985.

49. Colquitt, J.A.; Jackson, C.L. Justice in teams: The context sensitivity of justice rules across individual and team contexts. J. Appl. Soc. Psychol. 2006, 36, 868-899. [CrossRef]

50. Leventhal, G.S. What should be done with equity theory? New approaches to the study of fairness in social relationships. In Social Exchange: Advances in Theory and Research; Gergen, K., Greenberg, M., Willis, R., Eds.; Plenum Press: New York, NY, USA, 1980; pp. 27-55.

51. Greenberg, J. The social side of fairness: Interpersonal and informational classes of organizational justice. In Justice in the Workplace: Approaching Airness in Human Resource Management; Cropanzano, R., Ed.; Erlbaum: Hillsdale, NJ, USA, 1993 ; pp. 79-103.

52. Reknes, I.; Glambek, M.; Einarsen, S.V. Injustice perceptions, workplace bullying and intention to leave. Empl. Relat. 2020, 43, 1-13. [CrossRef]

53. Tuckey, M.R.; Searle, B.J.; Boyd, C.M.; Winefield, A.H.; Winefield, H.R. Hindrances are not threats: Advancing the multidimensionality of work stress. J. Occup. Health Psychol. 2015, 20, 131-147. [CrossRef]

54. Semmer, N.K.; McGrath, J.E.; Beehr, T.A. Conceptual issues in research on stress and health. In Handbook of Stress Medicine and Health, 2nd ed.; Cooper, C.L., Ed.; CRC Press: New York, NY, USA, 2005; pp. 1-43.

55. Schilpzand, P.; de Pater, I.E.; Erez, A. Workplace incivility: A review of the literature and agenda for future research. J. Organ. Behav. 2016, 37, S57-S88. [CrossRef]

56. Salin, D. The prevention of workplace bullying as a question of human resource management: Measures adopted and underlying organizational factors. Scandin. J. Man. 2008, 24, 221-231. [CrossRef]

57. Kidder, D.L. Restorative justice: Not "rights", but the right way to heal relationships at work. Int. J. Confl. Manag. 2007, 18, 4-22. [CrossRef] 
58. John, W.S.; Johnson, P. The pros and cons of data analysis software for qualitative research. J. Nurs. Sch. 2000, 32, 393-397. [CrossRef] [PubMed]

59. Rayner, C.; Lewis, D. Managing workplace bullying: The role of policies. In Bullying and Harassment in The Workplace; Einarsen, S.V., Hoel, H., Zaph, D., Cooper, C.L., Eds.; CRC Press: Boca Raton, FL, USA, 2020; pp. 497-519.

60. Safe Work Australia. Preventing Psychological Injury under Work Health and Safety Law: Fact Sheet. 2014. Available online: https://www.safeworkaustralia.gov.au/doc/preventing-psychological-injury-under-work-health-and-safety-lawsfact-sheet (accessed on 18 June 2021).

61. Safe Work Australia. Work-Related Psychological Health and Safety: National Guidance Material. 2019. Available online: https:/ / www.safeworkaustralia.gov.au/doc/work-related-psychological-health-and-safety-systematic-approach-meetingyour-duties (accessed on 13 May 2021). 